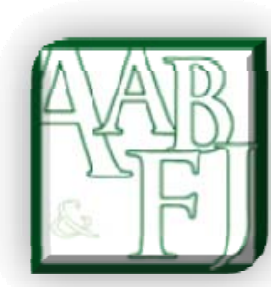

\title{
The Imperfect Match of Public Accountability of State-Owned Enterprises and Private-Sector-Type Financial Reporting: The Case of Italy
}

\author{
Francesco Capalbo ${ }^{1}$ and Ricardo Palumbo ${ }^{2}$
}

\begin{abstract}
State-owned enterprises (SOEs) are legally private entities used in many jurisdictions to satisfy public needs, mostly through extensive consumption of public funds. While the nature of purposes pursued and of resources employed affects their accountability in a public sense, their financial reporting requirements are set on the basis of their legal form and this may end up generating a misalignment between accountability and reporting. Such a misalignment significantly impairs the effectiveness of financial reporting and limits the relevant public authorities' ability to control. The case of Italian SOEs is a fine example. These were created as incorporated entities fully or partially owned by local governments willing to dislocate the production of public services, especially utilities. Such companies have benefitted, thanks to the chosen legal form, from a private style financial reporting model that has significantly eased the controls normally existing on public administrations, and which has favoured massive misuse of public funds and largely illegal management conducts. This paper advocates for significant amendments to the financial reporting model they inherit from the legal form, in order to realign their private-style accounting obligations with their public-style accountability.
\end{abstract}

Keywords: State owned enterprises; Accountability; Reporting; Statement of Corporate Intent.

JEL Codes: M40

\footnotetext{
${ }^{1}$ La Seconda Universita' di Napoli, email: f.capalbo@francescocapalbo.it

${ }^{2}$ University of Chieti-Pescara
} 


\section{SOE and the reasons for Public Style accountability}

Accountability is certainly one of the concepts referred to most often in accounting literature, but it is also-perhaps for that very reason-among the most ambiguously defined concepts (Sinclair 1995). ${ }^{3}$ Yet the term's etymology is relatively simple. To account for something means to cite the reasons that explain a certain behaviour (Roberts \& Scapens 1985; Thynne \& Goldring 1987; Jones 1992).

The chameleonic nature the concept acquires under the different definitions suggested for it (Sinclair 1995) is most likely due not to different interpretations of the term, but to the variability of the objectives assigned to people who are required to account for their behaviour ("accountors"), and to the variability of the cognitive and control priorities of the people (“accountees”) to whom account is supposed to be given (Van Thiel 2000). ${ }^{4}$

It is probably this circumstance that explains the main differences normally attributed to the concept of accountability in the private sector and the public sector. Actually, while in both cases it always means 'to answer for something', the profound differences that may exist in the purposes assigned to the accountors and in the cognitive and control needs deriving from the different nature of the resources used can entail changes in the forms and contents of the necessary reporting instruments.

As to the purpose, when gaining a profit is the one that prevails, as it is mostly (though not exclusively ${ }^{5}$ ) the case in the private sector, reporting is greatly simplified. People running a profit orientated entity are asked to create value for its investors and, since in a monetary economy this means assuring stockholders that they can earn more money than they invested, the more that cash flows are generated, the higher the value created for the investors. Thus the contents, the forms and the rules governing reporting instruments are aligned to the need to represent a business's capacity to create cash (IASB 2010, par. OB3). ${ }^{6}$

If an entity's purpose is not to turn a profit, as is typically the case in public-sector, reporting is more complicated (Hughes 1992). ${ }^{7}$ If a company sells its output at a price that does not reflect its fair market value, or just gives its goods or services away, then its economic balance cannot be defined in terms of financial remuneration of invested capital (Walker 1989; Pallot 1992; Airoldi et al. 2005; D’Alessio 2008; Marchi 2011). ${ }^{8}$ Measuring the value the entity creates for its owners becomes decidedly more complex (Capaldo 1995; Borgonovi 2005). The degree to which entities achieve the purposes assigned to them-in particular entities delivering essential services_cannot indeed be measured by quantifying their past and future cash flows. ${ }^{9}$ This situation requires the development of broader sets of

\footnotetext{
${ }^{3}$ Many different meanings have been attributed to the term, and they often spill over into areas traditionally reserved for other concepts, such as responsibility, ethics, professional standards, or control. The idea of accountability has even been used to evoke images of reliability, loyalty and justice, or as a synonym for good government (Mulgan 2000; Van Thiel 2000; Bovens 2007).

${ }^{4}$ As early as a century ago, the literature clearly recognised that even within the sphere of private for-profit enterprises, each different cognitive need was matched by just as many financial statements (Pantaleoni 1904).

${ }^{5}$ As Farneti notes (2007, p. 12), “[A] public-sector company is not necessarily a not-for-profit company, and a private-sector company is not necessarily a for-profit company”.

${ }^{6}$ This is consistent with the purpose of business enterprises, which-as clearly recognized by the FASB in its conceptual framework - is "to invest cash in non-cash resources to earn more cash" (FASB 1978, part. 139).

${ }^{7}$ Although a change of purpose does not necessarily change a company's essential features, the company is and always remains a "production fact" (Cavalieri 2010 p. 128) to which all the traditional principles of accounting and business economics continue to apply (Farneti 2000, p. 512; Viganò 2000, pp. 674-677; Catturi 2003).

${ }^{8}$ Generally speaking, the people to whom public-sector reporting is addressed are not interested in weighing different ways of allocating their resources; rather, they feel a need to judge the performance of managers who are responsible for productive operations that cannot be abandoned (Lennard 2007; Australian Accounting Standards Board et al. 2006; Mack \& Ryan 2006). Consistently, the IPSASB (2010), in its proposal for a conceptual-framework, placed decidedly more emphasis on the evaluation of directors (stewardship) than did FASB and IASB in their framework for the private sector.

${ }^{9}$ Even the identification of the economic entity to be satisfied seems anything but immediate (Ricci 2010).
} 
indicators that go beyond the logic of accounting income anchored to the financial effects of business transactions. Focusing on the substantive aspects of the production process can attempt to measure separately the degree to which the different purposes assigned are satisfied (Brealey et al. 1997). ${ }^{10}$

The nature of resources employed can also greatly affect contents and form of accountability. When the origin of the funds used and raised by an entity are in the public sphere, this surely enhances the perception and relevance of the obligations of lawfulness compared with what happens in the private sphere. A large part of the cognitive interest is shifted from the results to the manner of production, in particular to their level of lawfulness and transparency. The ethical dimension is certainly heightened, and in those circumstances where the end can never justify the means, those that do not comply fully with the law run foul of the shared judgment of the community to which their output is delivered. ${ }^{11}$

State Owned Enterprises (SOEs) are quite a wide concept, since they can have several different forms and natures according to the peculiarity of the legal environment in which they are designed and operate. To the purpose of such work, we intend SOEs as limited companies that are partially or totally owned by a central or a local government, or even by an Agency controlled by them.

Sometimes these entities can operate in the market at terms and for purposes similar to those pursued by private-sector companies, and whose use of public resources is limited to their original capital endowment. In these cases, the public shareholder will certainly face the problem of incorporating in its "own" accountability the reporting of the results of its investment, and this situation can generate, for example, particular issues such as those related to reconciling the data derived from the accrual-based accounting system that corporations use and those derived from the shareholder's own accounting system, which is generally cash-based accounting. In these cases, though, one cannot speak of an alteration of the company's accountability. These are simply needs that remain in the shareholder's sphere and do not modify the company's ultimate purpose or its financing methods. Otherwise, one would have to postulate the need to modify the reporting of any company whose shareholders have sold their shares to a public administration.

More often, though, SOE are vehicles used to pursue public purposes ${ }^{12}$, and they do so through wide use of public funds ${ }^{13}$, and when this is the case, for the reasons just mentioned,

\footnotetext{
${ }^{10}$ Stakeholders' interests often conflict with each other. For instance, some citizens expect SOEs to give priority to environmental concerns, some think the need to reduce the costs of public management should prevail, others believe the primary goal should be to guarantee the quality of the services delivered, and still others believe employment is the greatest need.

${ }^{11}$ As the Corte dei Conti's Control Division for the Lombardy Region put it (Corte dei Conti 2008d, p. 18), "The dynamics of the business, judged by the criteria of economic viability, efficiency and efficacy, and assessed in the dimension given to art. 97 of the Constitution by constitutional case law, is thus a constitutive element of lawfulness in the public administration, and also marks the conditions for its protection. If related to widespread or anonymous interests, this can be achieved through forms of control, both internal and external, intended to make sure that power is exercised for the purpose for which it was given, to measure the match between the activity and the concrete care of the interest, to improve the parameters of the service rendered, to avoid wasting public resources and to repress deviations and inefficiencies.” Corte dei Conti is the Italian Supreme Audit Institution that, according to article 100 of the Constitution, "exercises preventive control over the legitimacy of Government measures, and also ex-post auditing of the administration of the State Budget. It participates, in the cases and ways established by law, in auditing the financial management of the entities receiving regular budgetary support from the State. It reports directly to the Houses on the results of audits performed.” It is a body with jurisdictional competence in matters of public accounts and in other matters laid out by law.

12 On the relationships between pursuit of profit and corporate form, see Santini 1973, Antonioli 2008 and Ferrara and Corsi 2009.

${ }^{13}$ In this sense, the number of companies whose accountability differs from the one that underlies the reporting model established by the Civil Code might be broader than the number of companies just owned by public
} 
substantial change occurs in the cognitive and control needs of the authorities to which the information is reported. This, in turn, would require different forms and contents of their reporting model (Hughes 1992; Mussari 1994; Bovens 2007; Christiaens and Rommel 2008).

In other words, in line with the objective character of the prevalent notion of an "entity governed by public law"14 and with the positions expressed in some case law on the nature of SOEs (Corte dei Conti 2008b), the contents, priorities and forms of accountability of a company owned by a public administration are modified, and the financial reporting model, as already authoritatively requested (OECD 2005; Assonime 2008), should then be consequently adapted.

What creates a public style accountability of SOE, therefore, is not so much by the nature of the shareholder, but rather the purposes assigned to it and by the nature of the resources used. That means that we might have a public accountability also for an entity that is not owned at all by any public entities, but that has been assigned public funds or public goals, as in the case of those companies entitled to gather taxes in the name of local or central government. The scope of this work is limited to SOE however.

\section{Italian SOEs: legal and accounting background}

In the last decade, the operations of Italian public administrations were characterised by a growing trend to outsource their production of goods and services to partly or wholly stateowned corporations (Corte dei Conti 2010; Unioncamere 2009).

Their choice of the corporate form was not due to its alleged capacity to guarantee efficiency and efficacy in public-sector production processes. Rather, it was due to the prevailing approach of the governing and controlling institutions, which considered only the private nature of the corporate form, without taking into necessary consideration the public nature of the activities performed and the resources employed (Corte dei Conti 2008c; Corte dei Conti 2011; Ristuccia 2011 ).

According to the system that currently prevails in Italy, SOEs-whatever their purposes or the nature of their resources-must comply with the rules established by the Civil Code, hence they follow the whole reporting system developed for the private sector without additions or changes (Cassation, ruling 26806/2009). ${ }^{15}$

Therefore, while the purposes sought and the resources used were characterising their accountability in a public-style, the financial reporting model stayed the same as though for profit orientated companies financed with private funds. This has created a misalignment that has resulted in huge areas left practically free from control. The resulting simplicity with which public resources could be turned to private purposes was the real reason for the impressive success of the corporation as the form preferred by public administrations. ${ }^{16}$ For

administrations. The IPSASB, for example, believes that a company can be characterised as subject to public law even if no public entity holds any of its capital, provided that the financial resources used in its management derive primarily from public sources (IPSASB 2011, par. 1.3).

${ }^{14}$ This aspect is well clarified in EEC Directive 50 of 1992, which states that the term "Body governed by public law means any body: established for the specific purpose of meeting needs in the general interest, not having an industrial or commercial character, and; having legal personality and; financed, for the most part, by the State, or regional or local authorities, or other bodies governed by public law; or subject to management supervision by those bodies; or having an administrative, managerial or supervisory board, more than half of whose members are appointed by the State, regional or local authorities or by other bodies governed by public law."

${ }^{15}$ Cassation is the is the major court of last resort in Italy. Similar indications are also set out in the Sicilian TAR (Regional Administrative Court), Catania III, 13 August 2002, no. 1446, and in the Veneto TAR, I, 4 April 2002, no. 1234.

${ }^{16}$ Italy's Public Function Department reported that 7,006 state-owned entities existed in 2009, but this figure was a downward approximation because it did not include entities wholly or partly owned by the Regions or the 
each euro spent by the local councils of the seven largest Italian municipalities, about seven are spent by the companies that participate.

State-owned companies (SOEs) ${ }^{17}$ have been used to: circumvent budget restrictions imposed by the so-called "Growth and Stability Pact" (GSP); to increase public administrations' "formal" capacity to contract debts; to exceed the ceilings imposed by the prohibition of borrowing to finance current spending; to avoid having to comply with the competitive hiring and procurement procedures that public administrations are required to follow; to overrun contractual ceilings on management remuneration; and to avoid obligations to cover budget commitments-obligations that are typically reported in financial accounting but are absent, or merely optional, in economic accounting (Ristuccia 2011, Corte dei Conti 2008a). Italian lawmakers, faced with the enormity of these types of conduct, have sought to realign the behaviour of SOEs at least to the general principles applicable to the management of public resources. These attempts have almost entirely neglected the control and reporting aspects, and have not created a model of governance, reporting and control for state-owned companies, a model independent and distinct from the one applicable to all other corporations.

To grasp a quick and essential understanding of the consequences of the misalignment between SOE public accountability and their private style reporting, a search was run on Google with a query asking to identify all the pages with the words: "amministrazioni pubbliche" (public administration) and "società participate" (SOE, both central and local government). The result showed some 15,000 pages. The search was then refined by adding some other words and the result was as follows:

\footnotetext{
State, and because it was based on information supplied by the public administrations themselves, many of which had failed to provide any. The Corte dei Conti, based on specific investigations (Corte dei Conti 2008c, 2008b, 2010), indicated a total of 6,588 state-owned entities during the four-year period 2005-08, but this figure too was a downward approximation because it was based on questions that received a response rate of $76 \%$, and because it did not include any public administrations other than municipalities and provinces. A different figure was reported in a 2009 Unioncamere study which, based on the data contained in the business registers kept by the provincial Chambers of Commerce, found that around 5,128 companies were owned by a total of 7,651 entities of various levels, from Regions to Mountain Communities. If on the one hand the data resulting from all these studies should be adjusted downward because of the great risk that companies whose capital is owned by multiple public administrations were counted twice or more, on the other hand a much larger upward adjustment would be needed to take account of companies that are directly owned by other SOEs. UnionCamere is the the national body that gathers all the local Chambers of Commerce.

17 Though we use the term "State-owned" corporation, we refer to corporations owned by government institutions at any level, including municipalities, provinces, Regions and so on, as well as the national government.
} 


\begin{tabular}{|l|r|r|}
\hline Words in the pages & No. pages & \% \\
\hline $\begin{array}{l}\text { Amministrazioni pubbliche (Public administration), } \\
\text { società partecipate (SOE) }\end{array}$ & 15,000 & 52 \\
\hline $\begin{array}{l}\text { Amministrazioni pubbliche (Public administration), } \\
\text { società partecipate (Public administrations), perdita e/o } \\
\text { perdite (loss) }\end{array}$ & 7,800 \\
\hline $\begin{array}{l}\text { Amministrazioni pubbliche (Public administration), } \\
\text { società partecipate (Public administration), dissesto e/o } \\
\text { dissesti (collapse) }\end{array}$ & 3,560 \\
\hline $\begin{array}{l}\text { Amministrazioni pubbliche (Public administration), } \\
\text { società partecipate (Public administration), spreco e/o } \\
\text { sprechi (misuse) }\end{array}$ & 2,500 & 28 \\
\hline $\begin{array}{l}\text { Amministrazioni pubbliche (Public administration), } \\
\text { società partecipate (Public administration), follia } \\
\text { (madness) }\end{array}$ & 511 & 3 \\
\hline $\begin{array}{l}\text { Amministrazioni pubbliche (Public administration), } \\
\text { società partecipate (Public administration),, “fuori } \\
\text { controllo"(out of control) }\end{array}$ & 357 & 2 \\
\hline
\end{tabular}

\section{The amendments to be taken to a limited company financial reporting model in the cases of SOEs with public accountability}

An entity that decides to operate in the market in the form of a limited company has to comply with all the accounting requirements that the relevant legislation establishes in the interest of third parties and, more generally, in the overall economic environment. This rule has to be valid also for public administrations deciding to use limited companies to achieve their goals and to perform their duties.

In these terms, SOEs certainly have to comply with all the financial reporting obligations established for any limited companies. Nonetheless, when it is clear that their accountability gets more complicated and that this creates a misalignment with the reporting requirements existing for private limited companies, local and central governments owning the companies should take any possible action to amend and integrate those requirements.

\subsection{Amendments suggested because of the different nature of purposes assigned: the Australian solution of the Statement of Corporate Intents}

Any reporting model should always stem from a full and clear understanding of the purpose assigned to the accountor. And so, if the main goal to be achieved is not profit, the reporting model cannot rotate around the concept of financial income, as is the case for profit orientated private companies. Failing to recognise that will lead to repeating the same mistakes incurred when, within the New Public Management (NPM) process, private reporting tools were exported to the public administration. At that stage, many authors, though recognising the NPM's merits, contested its accounting implications, on the grounds that it placed too much emphasis on the financial and economic aspects alone (Guthrie et al. 1990,; Parker and Gould 1999). It preferred measurement models and synthetic indicators (income first and foremost) that did not enable explicit representation of the degree to which public entities had achieved goals for which they have specific mandates (Parker and Gould 1999). There were also remarks in terms of reduction in disclosure of non-accounting and non-financial information (Parker and Gould 1999), subordination of the concept of 
accountability to that of accounting (Luke 2010), and excessive priority to efficiency and "value for money" than to efficacy and probity (Hopwood 1994). An enterprise reporting a generous financial income is not necessarily achieving its goals and meeting the needs of its stakeholders if it was not created for that purpose, as this is the case for most SOEs.

This was quite clear to New South Wales (Australia) and New Zealand lawmakers. The regulations applicable to public-sector companies in those countries (New Zealand's State Owned Enterprise Act 1987 and Australia's State Owned Corporations Act 1989), establish specific reporting obligations that are "added" to the mainly economic and financial ones to which these entities are subject because of their legal form. This shows full awareness of the differences between the purposes assigned to the SOEs and the ones pursued by the privatesector companies whose financial reporting system they inherited.

Public-sector companies in Australian and New Zealand SOEs are required not only to be "successful businesses" and to operate with efficiency equal to if not better than comparable private-sector companies, but also pursue other decidedly less business-like goals. While the traditional financial-reporting model doubtless guarantees effective accountability vis-à-vis the first goal, the same cannot be said for the others. The Australian regulations, for example, require public-sector companies to (a) show a sense of social responsibility in having regard for the interests of the community in which they operate; (b) obey the principles of ecological and environmental sustainability; and (c) show a sense of responsibility for regional development and decentralisation. ${ }^{18}$ These goals may prevail over the need for economic and financial efficiency. Verification of the degree to which the goals are met implies applying accountability instruments that differ from the ones developed by for-profit companies in a conceptual framework that does not presuppose purposes of that kind. If the Australian government asks the state-owned Port Kembla Corporation to promote harbour development and safety, or if it asks the Macquaire Generation to cut the cost of electricity and further the country's development, or if it asks the Hunter Water Corporation to safeguard the population's health and promote urban development, it can certainly not then demand that the company's profit or loss be represented by the degree to which the assigned goals have been met. The law requires the directors of these companies and of all other SOEs not only to discharge the accounting and reporting obligations they have as corporations, but also to file a "Statement of Corporate Intent" in which they set forth clearly, and with reference to all their subsidiaries and affiliates as well, at least the following information:

- objectives pursued

- main undertakings

- nature and scope of future activities

- accounting policies

- performance targets and other indicators that can be used to measure the company's performance vis-à-vis its objectives ${ }^{19}$

\footnotetext{
${ }^{18}$ New Zealand's regulations pay more attention than Australia's to workers' needs, and further require publicsector companies to guarantee workplace safety and job creation, and to assure their employees fairness, impartiality, equal opportunity and possibilities for growth and development.

19 "Each statement of corporate intent is required to specify for the group comprising a State owned corporation and its subsidiaries, in respect of the financial year to which it relates and each of the 2 following financial years, the following information: (a) the objectives of the corporation and of its subsidiaries, (b) the main undertakings of the corporation and of its subsidiaries, (c) the nature and scope of the activities to be undertaken, (d) the accounting policies to be applied in the financial reports of the corporation and of its subsidiaries, (e) the performance targets and other measures by which the performance of the corporation and of its subsidiaries may be judged in relation to their stated objectives, (f) the kind of information to be provided to the voting shareholders by the corporation during the course of those financial years, including the information to be included in each half-yearly report, (g) such other matters as may be agreed on by the voting shareholders and the board from time to time.” State Owned Corporation Act 1989, sect. 22.
} 
Any change in the statement of intent must be agreed upon with the shareholders. Thus the Port Kembla Corporation, for example, would not only have a chance to clarify that one of its objectives is to increase workplace safety; it would also be able to list the indicators it plans to use to measure the degree to which it has met this goal, for instance the number of working hours lost because of accidents. At the end of the year, the directors are required to file an Annual Report on the activities carried on by the company and its subsidiaries and affiliates, in which they supply all the information necessary to judge the degree to which the objectives described in the Statement of Corporate Intent have been achieved. Pursuant to the Australian legislation, the annual report must also contain a specific paragraph in which the directors describe and explain all the discrepancies found between the final data and the goals set forth in the Statement of Corporate Intent.

The Statement of Corporate Intent therefore offers a useful solution to align the reporting model to the accountability needs of an entity that pursues both business-like and non business-like purposes, and its use should be advocated in all cases a SOE is set.

\subsection{Amendments suggested because of the different nature of resources employed}

When an entity uses public funds, this determines a mutation in the chain of accountability that becomes broader and longer. On the one hand, the "formal" owner (i.e. the principal, from the managers' standpoint) operates as an "agent" that acts for a third level, namely the board of directors of the substantive owner, i.e. the entity which in the last analysis bears the risks and gains the benefits of the business (Farneti 2007). ${ }^{20}$ On the other hand, the traditional accountees situated along the classical vertical reporting line established by the stockholders are joined horizontally by many other stakeholders: citizens, public opinion, government spending control boards (Sinclair 1995, p. 220) and, in the broadest sense, the community in whose interest SOEs are always supposed to operate (Parker and Gould 1999, p. 114). For many reasons the accountability of SOEs tends to be closer to those of listed companies even if they are not listed on the markets. These companies, indeed, do not need to "go public" to be public, since they are already so by their very nature.

These differences imply revising some aspect of the financial reporting model of limited non listed companies that, in most cases, is the one legally relevant for SOEs.

A first concern is the option of small companies to publish abridged financial statements. This option, allowed by the legislation of many industrialised countries, is based on the assumption that in small companies the people who are actually interested in their enterprise's state of health and performance are already involved in some way in its management. They usually have speedier and more effective sources of information than year-end financial statements. Thus the likelihood that people who are effectively interested in their company's welfare and have only the annual financial statements as their sole or main source of information ("dependent users") is too low to justify the costs of preparing fulllength (or "general purpose") financial statements (Knutson and Wichmann 1984; Carsberg et al. 1985; McCahey and Ramsay 1989; Di Pietra 2005; Faux and Wise 2004). But while this assumption is perfectly reasonable in small private-sector companies where shareholders and directors tend to be the same people (Gnan 1998; Demartini 1999; Viganò 2007), it loses much of its force when the shareholders are public administrations. In these cases, regardless of the SOE's size, the shareholders and the managers can never be the same people. The public nature of their owners entails an evolution of the traditional agency relationship. The typical two-party relationship between principal and agent, where one prepares the financial statements and the other approves them, turns into a relationship involving at least three

\footnotetext{
20 "If the corporation is a public-sector entity or is owned by a public-sector entity, its owner is external to its management and answers to the users/consumers" (Farneti 2007, p. 11).
} 
parties. In fact, there exists a substantive ownership that coincides with the citizens (Farneti 2007), who in the last analysis bear the risks and gain the benefits of the business, but have nothing to do with drawing up the financial statements. This increases the risk that shareholders and directors, instead of being in conflict, have a common interest in presenting a doctored version of the year's results. ${ }^{21}$ This risk is increased by the political visibility of these companies (Watts and Zimmerman 1978). By amplifying the media's treatment of negative results, it makes especially odious the dissemination of messages that in the end are inevitably read as evidence of the "wasting of public resources". Similarly, the technical ease with which it is possible, in an accrual-based accounting system, to alter the result for the year through skilful use of non-monetary discretionary items makes earnings management policies that enable the acknowledgement of economic imbalances to be postponed to periods when other administrations will be "politically competent" seem especially attractive. SOEs should then be excluded from the benefit of the abridged financial statements, because in such contexts small size does not necessarily affect the needs of reporting and control. ${ }^{22}$ On the contrary, the distance that exists in these SOEs between the people who hold management power and those who bear all the risks and gain the benefits is so large that it seems advisable not only to prepare full length financial statements but also to subject them to forms of control and publicity similar to the ones prescribed for listed companies in order to protect shareholders who are just as distant from management (e.g. mandatory auditing, posting of the financial statements on the internet, preparation and publication of interim reports). Indeed, it would be very strange if the outsourcing (often merely formal) of an institutional activity were to enable so sharp a reduction of the obligations of transparency and control. ${ }^{23}$

For the same reasons, the financial statements of SOEs should also present a level of detail higher than the one the relevant legislation requires for private companies. In private sector financial statements are primarily orientated towards satisfying the information needs of parties outside the company; hence they have no immediate managerial functions. The documents included therein contain information regarding the company's financial position and financial performance, and are mainly intended to enable outsiders to evaluate the company's overall results of the year and its general state of health. They say little or nothing about how the business is run and/or the costs of individual transactions or processes. Shareholders who are less involved in the company's management and who wish to verify whether it is being conducted in accordance with its internal principles and rules will have to define further reporting obligations beyond the minimum ones prescribed by the relevant

\footnotetext{
${ }^{21}$ In the private sector, ownership concentration tends to align the managers' interests with those of the shareholders, thereby reducing the stimuli to alter the results. In the public sector however, even when managers and shareholders are aligned, there is always a third level of reporting that can stimulate "earnings management" activities, especially if they are intended to conceal economic imbalances (Capalbo et al. 2010). Exemplary studies have shown that unlike what happens in privately owned companies, in SOEs the concentration of ownership is not correlated to any reduction of policies of "managing" the results of the business (Ding et al. 2007).

${ }^{22}$ This choice was made in Australia, for example, where public entities are always deemed to be reporting entities and are therefore required to prepare full-length financial statements (Capalbo 2004; Walker 2007; Cheung et al. 2010). Similar considerations can be proposed for other size-related benefits, such as the possibility of not appointing a board of statutory auditors (or a single statutory auditor) and the possibility of not having the financial statements certified by independent auditors.

${ }^{23}$ As has already happened for public administrations since the enactment of Law 69 of 2009, I think every SOE should post its financial statements on its website, instead of just filing them with the Companies Register as all corporations are required to do. The people to whom these financial statements are addressed are not always located along the vertical axis of accountability, which is more respectful of a classical relationship between financial principal and agent. Some are also located along other dimensions related to the social sphere or the ethical, political or legal spheres (Gray and Jenkins 1993), and often have less technical competence for collecting relevant financial information.
} 
legislation, if they intend to exercise control extending from the results to the processes. Accordingly, if a public administration truly wishes to subject its subsidiaries to a type of control similar to that exercised over its own departments, it will necessarily have to go beyond the reporting system required for private companies. An example is provided by New Zealand's State Owned Enterprise Act (1986), whereby an SOE must be “an organisation that exhibits a sense of social responsibility by having regard to the interests of the community in which it operates and by endeavouring to accommodate or encourage these when able to do so."

In light of the above, it might be advisable to require subsidiaries to include in their financial statements at least:

(a) a reconciliation chart that details the costs recorded in the profit-and-loss account at a level consistent with the regulatory indications on expenditure control, and suitable to represent the total cost of the different types of services produced;

(b) a single chart of accounts that guarantees the "uniform" derivation of expenditure items;

(c) some form of legal compliance report that offers guarantees regarding compliance with the laws and above all with the internal procedures that may have been imposed by the parent company

Last but not least, the problem of prior authorisation of expenditures should be tackled and resolved. The financial reporting model normally defined for private companies establishes no obligation for prior financial coverage for companies' assumption of commitments. This would be contrary to the very essence of entrepreneurial risk. However, in a great many cases SOEs actually operate in a quasi-monopolistic system and can count from the outset on a well defined revenue flow crystallised in a service contract. In these cases, the need to preserve the financial equilibrium can thus prevail over entrepreneurial needs of elasticity. In also considering the preponderant need to guarantee continuity in the delivery of services that are often fundamental, it might be highly advisable to reassert in the corporate model the precious principle of financial equilibrium that is ignored in economic accounting, but is well known in public administration, by defining a prior-authorisation system similar to the one prescribed for public entities' own structures. This can prevent them from assuming commitments that the SOE cannot fulfill. This does not necessarily mean adopting authorisation-type cash accounting instead of accrual accounting; it simply means adding to the latter a preventive expenditure control mechanism.

\section{Summary and conclusions}

An SEO's accountability is affected when it pursues public purposes and does so through the use of public funds. The financial reporting model it derives from its legal form does not enable an appropriate and effective assessment of its performance vis-à-vis the different and more variegated purposes assigned to it, which are not limited to, and above all cannot be summarised as, the financial remuneration of the invested capital. Neither the confines nor the forms of reporting appear to be adequate for the greater and different needs of control implied by the public nature of the resources used.

The financial reporting model SOEs derive from their legal form need then to be integrated and adapted to reflect the different control and information needs generated by the public nature of purposes pursued and resources used. A Statement of Corporate Intent should be added to the financial statements to describe the non business like purposes of the company and the levels at which they have been achieved, while some part of the relevant financial reporting model should be adapted to reflect the enlargement that the use of public funds generate in the accountability chain. It is advisable to: a) eliminate the benefit of the 
short-form financial statements for all SOEs, even if small, b) require the appointment of a board of statutory auditors (or a single statutory auditor) regardless of the company's size, c) require publication of the financial statements on the internet and adoption of a single mandatory chart of accounts, d) require preparation and publication of interim financial statements, and e) require preparation and publication of the economic-financial budget with authorisation-type purposes.

\section{Bibliography}

Airoldi, G, Brunetti, G \& Coda, V 2005, Corso di Economia aziendale, Il Mulino, Bologna, . Antonioli, M 2008, Società a partecipazione pubblica e giurisdizione contabile, vol. 42, Giuffrè, Milan.

Assonime 2008, Principi di riordino del quadro giuridico delle società pubbliche. Assonime, Rome.

Australian Accounting Standards Board, Canadian Accounting Standards Board, Canadian Public Sector Accounting Board, New Zealand Financial Reporting Standards Board, and United Kingdom Accounting Standards Board 2006, The Objective of Financial Reporting and Qualitative Characteristics of Decision-Useful Financial Reporting Information. Application to Not-for-Profit Entities in the Private and Public Sector In The IASB/FASB Conceptual Framework Project's Preliminary Views on an Improved Conceptual Framework for Financial Reporting. IASB/FASB, London.

Borgonovi, E 2005, Principi e sistemi aziendali per le amministrazioni pubbliche, 5th edn, Egea , Milan..

Bovens, M 2007, 'Public Accountability', in E Ferlie, LE Lynn \& C Pollitt (eds), The Oxford Handbook of Public Management Oxford University Press (USA), New York. http://dx.doi.org/10.1093/oxfordhb/9780199226443.003.0009

Brealey RA, Cooper IA \&Habib MA 1997, 'Investment appraisal in the public sector', in Oxford Review of Economic Policy, vol. 13, no. 4, pp. 12-28. http://dx.doi.org/10.1093/oxrep/13.4.12

Capalbo, F 2004, Il sistema contabile australiano: attori e processi. Cedam, Padua.

Capalbo, F, D'Amico, L \& Palumbo, R 2010, 'Governo e performance nelle imprese partecipate di servizi pubblici: evidenze empiriche di Earnings Management nel trasporto pubblico locale', in XXXIII Convegno AIDEA, Bocconi University, Milan.

Capaldo, P 1995, 'Le aziende non profit tra Stato e mercato', paper presented at the XVIII Convegno Annuale dell'Accademia Italiana di Economia Aziendale (18th Annual Conference of the Italian Academy of Business Economics), Rome, September.

Carsberg, BV, Page, MJ, Sindall, AJ \& Waring I 1985, 'Small Company Financial Reporting', in Research Studies in Accounting, Institute of Chartered Accountants in England and Wales, London.

Catturi, G 2003, L'azienda universale: l'idea forza, la morfologia e la fisiolocia, Cedam, Padua.

Cavalieri, E 2010, 'Le nuove dimensioni dell'equilibrio aziendale. Contributo alla rivisitazione della teoria', Rivista italiana di ragioneria e di economia aziendale, no. 34, pp. 125-141.

Cheung, E, Evans, E \& Wright, S 2010, 'An Historical Review of Quality in Financial Reporting in Australia’, Pacific Accounting Review, vol. 22, no. 2, pp. 147-169. http://dx.doi.org/10.1108/01140581011074520

Christiaens, J \& Rommel J 2008, 'Accrual Accounting Reforms: Only for Businesslike (Parts of) Governments’, Financial Accountability \& Management, vol. 24, no.1, pp. 59-75. http://dx.doi.org/10.1111/j.1468-0408.2008.00443.x 
Corte dei Conti 2008a, Deliberazione n. 100, Corte dei Conti, Sezione di Controllo per la Regione Sicilia, Palermo.

— 2008b, Deliberazione n. 10: Relazione sull'indagine relativa alle società partecipate delle provincie e dei comuni della Regione Lombardia, Sezione di Controllo per la Lombardia, Milan.

2008c, Deliberazione n. 13: Stato dei controlli della Corte dei Conti sugli organismi partecipati dagli enti locali, Sezione delle Autonomie, Rome.

- 2008d, Deliberazione n. 270: Relazione sulle esternalizzazioni dei servizi pubblici negli enti locali della Regione Lombardia, Sezione di Controllo per la Regione Lombardia, Milan.

— 2010, Deliberazione n. 14: Indagine sul fenomeno delle partecipazion in società ed altri organismi da parte di comuni e province, Sezione delle Autonomie, Rome.

2011, Relazione sulll'attività svolta nell'anno 2010, Corte dei Conti, Rome.

D'Alessio, L 2008, Innovazione e accountability nella pubblica amministrazione: $i$ drivers del cambiamento. RIREA, Rome.

Demartini, P 1999, La comunicazione economico-finanziaria delle PMI. University of Urbino, viewed 20 August 2012, $<$ http://www.econ.univpm.it/ospiti/aidea/18121999/demartini.doc.em>..

Di Pietra, R 2005, Il progetto dello Iasb per la redazione dei bilanci delle PMI, Quaderni Senesi di Economia Aziendale e di Ragioneria, University of Siena, Siena.

Ding, Y, Zhang, H \& Zhang J 2007, 'Private vs State Ownership and Earnings Management: Evidence from Chinese Listed Companies', Corporate Governance: An International Review, vol. 15, no. 2,pp. 223-238.

Farneti, G 2000. 'Le aziende non profit e le peculiarità del loro sistema informativo', in E Vigano (ed.), Azienda. Contributi per un rinnovato concetto generale, Cedam, Padua. 2007, Economia d'azienda, vol. 65, FrancoAngeli, Milan.

FASB 1978, 'Objective of Financial Reporting by Business Enterprises', in Statement of Accounting Concept no. 1., Financial Accounting Standards Board of the Financial Accounting Foundation, Norwalk.

Faux, J \& Wise, V 2004, 'Differential Reporting Policy in a Changing Financial Environment', in MZ Hoque (ed.), Proceedings of International Business Research Conference 2004, World Business Institute, Melbourne.

Ferrara, F \& Corsi, F 2009, Gli Imprenditori e le società.Giuffrè, Milan .

Gnan, L, Airoldi, G \& Montemerlo, D 1998, 'Strutture proprietarie, complessità gestionale e sistemi di governance nelle piccole e medie imprese', in G Airoldi \& G Forestieri, Corporate governance: analisi e prospettive del caso italiano, ETAS, Milan.

Gray, A \& Jenkins, B 1993, 'Codes of Accountability in the New Public Sector', Accounting, Auditing \& Accountability Journal, vol. 6, no. 3. http://dx.doi.org/10.1108/09513579310042560

Guthrie, J, Parker, L \& Shand, D 1990, The Public Sector: Contemporary Readings in Accounting and Auditing, Harcourt Brace Jovanovich, Sydney.

Hopwood, A 1992, Accounting and the pursuit of efficiency, Sage Publications, London.

Hughes, O. 'Public Management or Public Administration?', Australian Journal of Public Administration, vol. 51, no. 3pp. 286-296.

International Accounting Standards Board (IASB) 2010, The Conceptual Framework for Financial Reporting, International Financial Reporting Standards Foundation, London.

International Public Sector Accounting Standards Board (IPSASB) 2010, Conceptual Framework for General Purpose Financial Reporting by Public Sector Entities: Role, Authority and Scope; Objectives and Users; Qualitative Characteristics; and Reporting Entity [Exposure Draft 1], International Federation of Accountants), Toronto. 
2011, Key Characteristics of the Public Sector with Potential Implications for Financial Reporting [Exposure Draft], International Federation of Accountants, Toronto.

Jones, GW 1992, 'The Search for Local Accountability', in S Leach (ed.), Strengthening Local Government in the 1990s, Longman, London.

Knutson, DL \& Wichmann, H 1984, 'GAAP Disclosures: Problem for Small Business', Journal of Small Business Management, vol. 22, no. 1, pp. 38-46.

Lennard, A 2007, 'Stewardship and the Objectives of Financial Statements: A Comment on IASB's Preliminary Views on an Improved Conceptual Framework for Financial Reporting: The Objective of Financial Reporting and Qualitative Characteristics of Decision-Useful Financial Reporting Information', Accounting in Europe, vol. 4, no. 1, pp. 51-66. http://dx.doi.org/10.1080/17449480701308774

Luke, B 2010, 'Examining Accountability Dimension in State-Owned Enterprises',Financial Accountability \& Management, vol. 26, no. 2, pp. 134-162. http://dx.doi.org/10.1111/j.1468-0408.2010.00496.x

Mack, J \& Ryan, C 2006, 'Reflection on the Theoretical Underpinnings of the General Purpose Financial Reports of Australian Government Departments', Accounting, Auditing \& Accountability Journal, vol. 19, no. 4, pp. 592-612. http://dx.doi.org/10.1108/09513570610679146

Marchi, L 2011, 'Integrazione pubblico-privato su metodologie e strumenti di controllo gestionale', Management Control, no. 2, pp. 5-8.

McCahey, JE \& Ramsay, AL 1989, Differential Reporting: Nature of the Accounting Standards Overload Problem and a Proposal for its Resolution. Australian Accounting Research Foundation, Caulfield.

Mulgan, R 2000 ““Accountability”: An Ever-Expanding Concept?’ Public Administration, vol. 78, no. 3,pp. 555-573. http://dx.doi.org/10.1111/1467-9299.00218

Mussari, R 1994, 'Accounting and Accountability in Italian Local Governments: Recent Changes and Challenges for the Future', Public Budgeting \& Finance, vol. 14, no. 4, pp. 54-70. http://dx.doi.org/10.1111/1540-5850.01020

Organisation for Economic Co-operation and Development 2005, OECD Guidelines on Corporate Governance of State-owned Enterprises. OECD Publications, Paris .

Accounting, Auditing \& Accountability Journal, vol. 5, no. 1.

Pantaleoni, M 1904, Alcune osservazioni sulle attribuzioni di valori: in assenza di formazioni di prezzi di mercato. Unione Cooperativa Editrice, Rome. Pallot, J 1992, 'Elements of a Theoretical Framework for Public Sector Accounting',

Parker, L\& Gould, G 1999, 'Changing Public Sector Accountability: Critiquing New Directions', Accounting Forum, vol. 23, no. 2, pp. 109-135.

Ricci, P 2010, Il soggetto economico nell'azienda pubblica. RIREA, Rome.

Ristuccia, M 2011, Relazione del procuratore generale all'inaugurazione dell'anno giudiziario 2011, Corte dei Conti, Adunanza delle SS.RR., Rome.

Roberts, J\& Scapens, R 1985, 'Accounting Systems and Systems of Accountability: Understanding Accounting Practices in Their Organisational Contexts', Accounting, Organizations and Society, vol. 10, no. 4, pp. 443-456. http://dx.doi.org/10.1016/0361-3682(85)90005-4

Santini, G 1973, 'Tramonto dello scopo lucrativo nelle società di capitali', Rivista di diritto civile, vol. 19, no. 0,pp. 151-173.

Sinclair, A 1995, 'The Chameleon of Accountability: Forms and Discourses', Accounting, Organizations and Society, vol. 20, nos. 2-3, pp. 219-237.

http://dx.doi.org/10.1016/0361-3682(93)E0003-Y 
Thynne, I\& Goldring, J 1987, Accountability and Control: Government Officials and the Exercise of Power, Law Book Company, Sydney.

Unioncamere 2009, Secondo Rapporto sulle società partecipate da Comuni, Province, Regioni e Comunità Montane (Second Report on Enterprises Owned by Municipalities, Provinces, Regions and Mountain Communities), Unioncamere, Rome.

Van Thiel, S 2000, Quangocratization: Trends, Causes and Consequences. Interuniversity Center for Social Science Theory and Methodology, Groningen.

Viganò, E 2000, 'Il concetto generale di azienda', in E. Viganò (ed.), Azienda. Primi contributi per un rinnovato concetto generale, Cedam, Padua.

- Contenuto e finalità del bilancio (come modello convenzionale per l'impresa caratteristica), Cedam, Padua.

Walker, R 1989, 'Should There Be Common Reporting Standards for the Public and Private Sectors?’, in by ANU/CPA Australia (ed.), Annual Research in Government Accounting, Australian National University/CPA, Canberra.

Walker, RG 2007, 'Reporting Entity Concept: A Case Study of the Failure of PrinciplesBased Regulation’, Abacus, vol. 43, no. 1, pp. 49-75. http://dx.doi.org/10.1111/j.1467-6281.2007.00217.x

Watts, RL\& Zimmerman, JL 1978, 'Towards a Positive Theory of the Determination of Accounting Standards’, Accounting Review, vol. 53, no. 1, pp. 112-134. 